\title{
Analisis Kualitas Media Pembelajaran Insektarium dan Herbarium untuk Mata Pelajaran Biologi Sekolah Menengah
}

\author{
Muhammad Joko Susilo \\ Progam Studi Pendidikan Biologi, FKIP, Universitas Ahmad Dahlan \\ Kampus III, Jl. Prof. Dr. Soepomo, SH, Yogyakarta, 55164 Indonesia \\ surat elektronik: jokoms_uad@yahoo.com
}

\begin{abstract}
ABSTRAK
Media pembelajaran berperan penting dalam proses pembelajaran. Keberadaannya mampu menghantarkan siswa menuju proses pembelajaran yang utuh. Media pembelajaran yang berbasis alam diharapkan mampu membangkitkan semangat siswa, dalam hal ini yaitu media pembelajaran insektarium dan herbarium. Meskipun demikian, kualitas media tersebut tetap dinomor satukan. Penelitian ini bertujuan untuk mengetahui kualitas media pembelajaran yang dikembangkan dalam bentuk insektarium dan herbarium dari penelitian mahasiswa.

Penelitian ini merupakan penelitian deskriptif dengan kajian laporan hasil penelitian. Metode yang dilakukan yaitu dengan Comparative of Result Experiment (CRE), kemudian dianalisis secara mendalam terhadap kualitas media pembelajaran yang meliputi aspek kesesuaian dengan kurikulum, kualitas materi, kesesuaian bahasa, penyajian, kemudahan,dan manfaat dari media pembelajaran. Pengumpulan data dilakukan dengan dokumentasi. Teknik analisis data dilakukan secara kualitatif.

Berdasarkan hasil analisis kualitas media pembelajaraninsektarium dan herbarium memenuhi tuntutan kompetensi dalam Kurikulum 2013, khususnya pada KD 3.8 dan KD 3.3 pada jenjang Sekolah Menengah. Ditinjau dari berbagai aspek, media insektarium dan herbarium pada aspek kualitas materi memperoleh skor rata-rata 97.83\%, kesesuaian bahasa $100 \%$, penyajian $98.34 \%$, kemudahan $94.20 \%$, dan manfaat 98.66\%.Secara keseluruhan media insektarium dan herbarium yang dikembangkan memenuhi syarat sebagai bahan ajar yang berkualitas dengan kualitas baik dan layak digunakan untuk menunjang pembelajaran.
\end{abstract}

Kata kunci: Kualitas, Media Pembelajaran, Insectarium, Herbarium

\section{Pendahuluan}

Media pembelajaran memiliki peranan penting dalam keberlangsungan proses belajar mengajar. Penggunaan media pembelajaran yang optimal mampu mempermudah siswa dalam mencerna materi pelajaran. Meskipun demikian, tidak semua media pembelajaran dapat dijadikan sebagai solusi yang tepat dalam mengefektifkan proses pembelajaran. Oleh karena itu, seorang guru dituntut lebih kreatif dalam mengembangkan media pembelajaran, serta lebih selektif dalam memilih media pembelajaran.

Kedudukan media pembelajaran ada dalam komponen metode pembelajaran sebagai salah satu upaya untuk mempertinggi proses interaksi guru dengan siswa dan interaksi siswa dengan lingkungan belajarnya. Oleh sebab itu, fungsi utama dari media pembelajaran adalah sebagai alat bantu mengajar, yakni menunjang penggunaan metode mengajar yang diperlukan guru. Melalui penggunaan media diharapkan dapat mempertinggi kualitas proses belajar mengajar yang pada akhirnya dapat mempengaruhi kualitas belajar siswa. Manfaat penggunaan media dalam proses pembelajaran antara lain: (I) Pembelajaran akan lebih menarik perhatian siswa, (2) bahan ajar akan menjadi lebih jelas maknanya sehingga dapat dipahami siswa, (3) metode mengajar menjadi lebih bervariasi sehingga siswa tidak bosan, (4) siswa lebih banyak melakukan kegiatan belajar seperti mengamati, mendemonstrasikan tidak hanya mendengar guru (Arsyad, 2006: 2).

Saat ini media pembelajaran sangat dibutuhkan keberadaannya karena untuk menunjang proses pembelajaran. Beberapa fakta mengenai proses pembelajaran yang monoton karena ketidakhadiran media pembelajaran maupun kurangnya kreativitas pendidik terjadi dibeberapa sekolah baik jenjang SMP maupun SMA. Salah satunya didasarkan pada hasil wawancara dengan Bapak Djoko Supadjiyono, S. Pd. selaku guru Biologi kelas X di SMA Negeri I Candimulyo, bahwa proses pembelajaran biologi pada 
materi Insekta di kelas memang tidak efektif. Ketidakefektifan ini dikarenakan materi insekta sangat banyak yaitu terdiri atas klasifikasi serangga yang beragam dengan istilah-istilah latin yang sulit untuk dipahami. Bapak Djoko Supardjoyono, S. Pd. juga menjelaskan, bahwa Beliau dalam menjelaskan materi insekta dengan beberapa buku paket, tetapi siswa kurang memahami materi dan bingung saat diberi pertanyaan tentang materi yang sedang dipelajari. Berdasarkan kondisi tersebut, dibutuhkan sebuah pembelajaran inovatif yang dapat menciptakan suasana belajar di kelas tidak lagi monoton (Rizkyana, 2015).

Selain kasus yang terjadi di SMA N I Candimulyo tersebut, hal yang sama terjadi di SMP N 2 Kejobong. Berdasarkan observasi dan wawancara dengan guru bidang studi IPA yang dilakukan di SMP N 2 Kejobong pada tanggal 7 April 2014 diketahui bahwa dalam proses pembelajaran biologi dengan materi tumbuhan paku (Pteridophyta) umumnya masih menggunakan metode ceramah dan mengacu pada buku pembelajaran biologi. Hal ini menyebabkan proses pembelajaran biologi menjadi tidak menarik dan membosankan atau terlihat monoton. Banyak siswa beranggapan materi biologi tidak menyenangkan untuk dipelajari karena cenderung menghafal tulisan-tulisan dan nama-nama ilmiah dan akhirnya siswa menjadi jenuh dan bosan. Kondisi tersebut antara lain disebabkan kurangnya pemanfaatan media pembelajaran atau alat peraga dalam proses pembelajaran. Penyebab lain adalah kurangnya memanfaatkan objek-objek alam sekitar sebagai media pembelajaran (Aggraeni, 2015).

Berdasarkan persoalan tersebut dapat diketahui bahwa guru masih kurang memaksimalkan pembelajaran. Hal ini terlihat dari proses pembelajaran yang monoton dan membosankan siswa. Sementara itu, di perguruan tinggi tidak sedikit pula mahasiswa calon guru yang melakukan penelitian untuk mencarikan solusi terhadap persoalan tersebut, misalnya dengan mengembangkan media ajar herbarium dan insektarium.Menurut Jumar (Mukaromah, 20II: 3), insektarium merupakan tempat penyimpanan koleksi spesimen Insekta, baik awetan basah maupun awatan kering. Insektarium sering menampilkan berbagai jenis serangga, koleksi serangga merupakan bahan untuk belajar struktur tubuh serangga secara mendalam, terutama yang berhubungan dengan ciri khasnya, sehingga kita lebih mudah mengenal dan menggolongkannya bila suatu waktu menjumpainya kembali di lapangan. Sedangkan menurut Purwanti (2012), herbarium merupakan koleksispesimen yang telah dikeringkan/diawetkan biasanya disusun berdasarkan sistem klasifikasi. Fungsi dari herbarium yaitu untuk membantu identifikasi tumbuhan lainnya yang sekiranya memiliki persamaan ciri-ciri morfologinya. Insektarium dan herbarium merupakan salah satu sumber pembelajaran yang penting dalam ilmu biologi baik hewan insekta maupun tumbuhan, karena melalui media tersebut siswa dapat melihat secara langsung bentuk asli dari insecta maupun tumbuhan tersebut.

Insektarium dan herbarium merupakan media pembelajaran yang telah lama digunakan. Selain penggunaanya yang praktis dan ekonomis, insektarium dan herbarium dirasa menjadi solusi yang tepat karena dapat dibawa kemana saja, baik di kelas maupun di laboratorium. Tentu akan tidak memungkinkan apabila dalam pembelajaran, misalnya materi tumbuhan paku ataupun materi insekta siswa langsung diterjunkan ke lapangan. Karena selain mempertimbangkan alokasi waktu pembelajaran yang terbatas, keselamatan siswa juga menjadi pertimbangan yang utama.

Penggunaan media pembelajaran khususnya herbarium dan insektarium menjadi sangat diperlukan dalam proses pembelajaran biologi. Meskipun demikian, kualitas media pembelajaran yang dikembangkan tersebut tentunya menjadi menjadi hal utama yang harus tetap terjaga. Oleh karena masih diragukan terhadap media yang telah dikembangkan, maka perlu dilakukan pengujian kualitas terlebih dahulu.

\section{Metode Penelitian}

Penelitian ini merupakan penelitian deskriptif dengan kajian laporan hasil penelitian. Penelitiam ini mengkaji hasil penelitian Rizkyana (2015) yang berjudul Pengembangan Insektarium Sebagai Media Pembelajaran Biologi Pada Materi Insekta Untuk Siswa Kelas X SMA/MA dan penelitian Anggraeni (2015), yang berjudul Pengembangan Herbarium Sebagai Media Pembelajaran Biologi Pada Materi Tumbuhan Paku (Pteridophyta) Siswa Kelas VII SMP. Kedua penelitian tersebut termasuk penelitian Research and Development (R\&D). Metode yang dilakukan yaitu dengan Comparative of Result Experiment (CRE), kemudian dianalisis secara mendalam terhadap kualitas media pembelajaran yang meliputi aspek kesesuaian dengan kurikulum, kualitas materi, kesesuaian bahasa, penyajian, kemudahan, dan manfaat dari media pembelajaran. Pengumpulan data dilakukan dengan dokumentasi, sedangkan teknik analisis data dilakukan secara kualitatif.

\section{Hasil dan Pembahasan}

\section{A. Analisis Kesesuaian Media Pembelajaran dengan Kurikulum}

I.Analisis Kesesuaian pada Media Insektarium

Kompetensi Inti 3: Memahami, menerapkan, menganalisis pengetahuan faktual, konseptual, dan prosedural berdasarkan rasa ingin tahunya tentang ilmu pengetahuan, teknologi, seni, budaya, dan humaniora dengan wawasan kemanusiaan, kebangsaan, kenegaraan, dan peradaban terkait fenomena dan kejadian, serta menerapkan pengetahuan prosedural pada bidang kajian 
yang spesifik sesuai dengan bakat dan minatnya untuk memecahkan masalah.

Kompetensi Dasar 3. 8 Menerapkan prinsip klasifikasi untuk menggolongkan hewan ke dalam filum berdasarkan pengamatan anatomi dan morfologi serta mengaitkan peranannya dalam kehidupan.

Tabel I. Hasil Analisis Kesesuaian Media denganKompetensi Dasar 3. 8 Kurikulum 2013

\begin{tabular}{|c|c|c|c|}
\hline No. & Penjabaran KD 3.8 & $\begin{array}{c}\text { Indikator } \\
\text { Pembelajaran yang } \\
\text { Diharapkan }\end{array}$ & $\begin{array}{c}\text { Indikator } \\
\text { Pembelajaran } \\
\text { dari LHP dan } \\
\text { Produk }\end{array}$ \\
\hline I. & $\begin{array}{l}\text { Prinsip klasifikasi } \\
\text { untuk } \\
\text { menggolongkan } \\
\text { hewan ke dalam } \\
\text { filum }\end{array}$ & $\begin{array}{l}\text { Menerapkan } \\
\text { prinsip klasifikasi } \\
\text { hewan }\end{array}$ & $\begin{array}{l}\text { Menerapkan } \\
\text { prinsip klasifikasi } \\
\text { hewan } \\
\text { invertebrata }\end{array}$ \\
\hline 2. & $\begin{array}{l}\text { Pengamatan anatomi } \\
\text { dan morfologi } \\
\text { hewan }\end{array}$ & $\begin{array}{l}\text { Menggolongkan } \\
\text { hewan ke dalam } \\
\text { filum berdasarkan } \\
\text { pengamatan } \\
\text { anatomi dan } \\
\text { morfologi }\end{array}$ & $\begin{array}{l}\text { Menggolongkan } \\
\text { inverterata ke } \\
\text { dalam filum } \\
\text { berdasarkan } \\
\text { pengamatan } \\
\text { anatomi dan } \\
\text { morfologi }\end{array}$ \\
\hline 3. & $\begin{array}{l}\text { Peranan hewan } \\
\text { dalam kehidupan }\end{array}$ & $\begin{array}{l}\text { Menjelaskan } \\
\text { peranan hewan } \\
\text { bagi kehidupan }\end{array}$ & $\begin{array}{l}\text { Menjelaskan } \\
\text { peranan } \\
\text { invertebrata bagi } \\
\text { kehidupan }\end{array}$ \\
\hline
\end{tabular}

Berdasarkan Kompetensi Dasar 3.8 dapat diketahui bahwa materi yang disajikan dalam LHP (Laporan Hasil Penelitian) maupun produk secara keseluruhan sudah memenuhi tuntutan materi ajar dalam Kurikulum 2013. Dalam hal ini khususnya materi tentang klasifikasi invertebrata. Materi tentang klasifikasi hewan vertebrata belum terpenuhi.Hal ini karena, penelitian tersebut hanya mengkhususkan pada materi klasifikasi invertebrata.

2.Analisis Kesesuaian pada Media Herbarium

Kompetensi Inti 3 Memahami pengetahuan (faktual, konseptual, dan prosedural) berdasarkan rasa ingin tahunya tentang ilmu pengetahuan, teknologi, seni, budaya terkait fenomena dan kejadian tampak mata.

Komptensi Dasar 3.3 Memahami prosedur pengklasifikasian makhluk hidup dan benda-benda takhidup sebagai bagian kerja ilmiah, serta mengklasifikasikan berbagai makhluk hidup dan bendabenda tak-hidup berdasarkan ciri yang diamati.

Tabel 2. Hasil Analisis Kesesuaian Media dengan Kompetensi Dasar 3.3 Kurikulum 2013

\begin{tabular}{llll}
\hline No. $\begin{array}{l}\text { Tujuan pembelajaran } \\
\text { tuntutan Berdasarkan } \\
\text { KD 3.8 Kur I3 }\end{array}$ & $\begin{array}{c}\text { Indikator } \\
\text { Pembelajaran } \\
\text { yang Diharapkan }\end{array}$ & $\begin{array}{l}\text { Indikator } \\
\text { Pembelajaran dari } \\
\text { LHP dan Produk }\end{array}$ \\
\hline $\begin{array}{l}\text { Prosedur } \\
\text { pengklasifikasian } \\
\text { makhluk hidup } \\
\text { benda-benda } \\
\text { hidup }\end{array}$ & $\begin{array}{l}\text { Prosedur } \\
\text { pengklasifikasian } \\
\text { tak }\end{array}$ & $\begin{array}{l}\text { Prosedur } \\
\text { pengklasifikasian } \\
\text { benda mati }\end{array}$ \\
\hline 2. & Kerja ilmiah & $\begin{array}{l}\text { Menggunakan } \\
\text { prosedur ilmiah }\end{array}$ & $\begin{array}{l}\text { Menggunakan } \\
\text { prosedur ilmiah }\end{array}$ \\
\hline 3. & Mengklasifikasikan & Klasifikasi makhluk & Klasifikasi \\
\hline
\end{tabular}

$\begin{array}{lll}\text { makhluk hidup dan } & \text { hidup termasuk } & \text { tumbuhan paku } \\ \text { benda tak hidup } & \text { hewan dan } & \text { berdasarkan ciri- } \\ \text { berdasarkan ciri yang } & \text { tumbuhan } & \text { ciri morfologis } \\ \text { diamati } & \begin{array}{l}\text { berdasarkan ciri- } \\ \text { ciri yang diamati }\end{array} & \text { yang diamati } \\ \end{array}$

Berdasarkan Kompetensi Dasar 3.3 dapat diketahui bahwa materi yang disajikan dalam LHP maupun produk secara keseluruhan sudah memenuhi tuntutan materi ajar dalam Kurikulum 2013. Dalam hal ini khususnya materi tentang klasifikasi tumbuhan paku (Pteridophyta). Materi tentang klasifikasi tumbuhan lumut, tumbuhan tingkat tinggi, dan klasifikasi benda tak hidup belum terpenuhi. Hal ini karena, penelitian tersebut hanya mengkhususkan pada materi klasifikasi tumbuhan paku.

\section{B. Hasil Pengujian Media Pembelajaran Biologi Terhadap Aspek Kualitas Materi, Kesesuaian Bahasa, Penyajian, Kemudahan, dan Manfaat}

Tabel 3. Hasil Penilaian Kualitas Media Insektarium

\begin{tabular}{|c|c|c|c|c|c|}
\hline \multirow{2}{*}{ No. } & \multirow{2}{*}{ Aspek } & \multicolumn{2}{|c|}{ Skor Penilaian (\%) } & \multirow{2}{*}{ Total } & \multirow{2}{*}{$\begin{array}{l}\text { Rata- } \\
\text { Rata }\end{array}$} \\
\hline & & Insektarium & Herbarium & & \\
\hline \multicolumn{2}{|c|}{ I. Kualitas Materi } & 98.62 & 97.03 & I95.65 & 97.82 \\
\hline \multicolumn{2}{|c|}{ 2. Kesesuaian Bahasa } & 100 & 100 & 200 & 100 \\
\hline \multicolumn{2}{|c|}{ 3. Penyajian } & 99.19 & 97.5 & I96.69 & 98.34 \\
\hline \multicolumn{2}{|c|}{$\begin{array}{l}\text { 4emudahan } \\
\text { Penggunaan }\end{array}$} & 92.23 & 96.18 & I88.4I & 94.20 \\
\hline \multicolumn{2}{|c|}{ 5. Manfaat } & 99.66 & 97.66 & 197.32 & 98.66 \\
\hline
\end{tabular}

$$
\begin{aligned}
& \text { Keterangan } \\
& \text { Kategori } \text { : skor }>80 \text { baik } \\
&: \text { skor70-80 cukup } \\
&: \text { skor }>70 \text { kurang }
\end{aligned}
$$

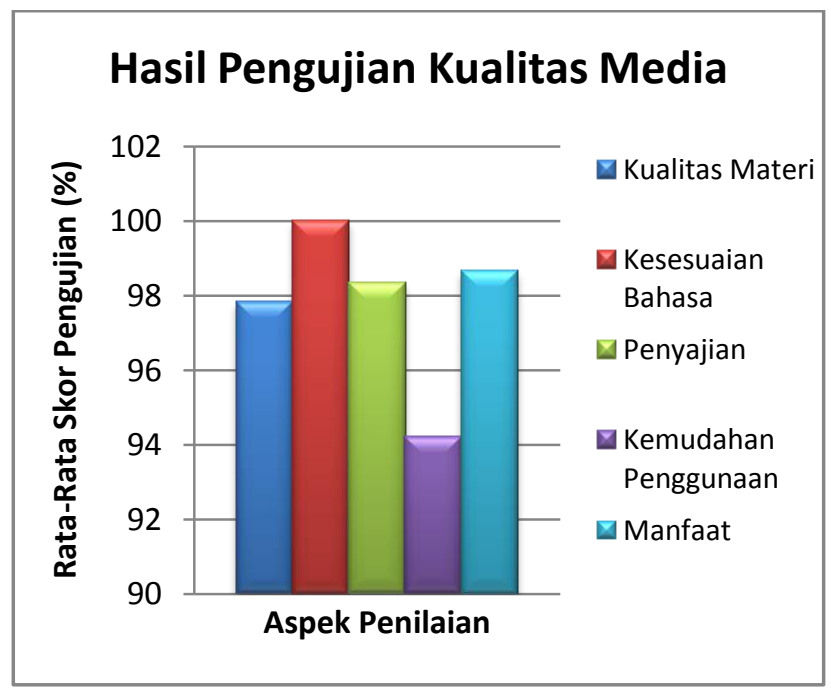

Gambar I. Diagram Batang Persetase Rata-Rata Hasil Pengujuan Kualitas Media

Berdasarkan hasil pengujian kualitas media pembelajaran pada Tabel 3. dan Gambar I. dapat diketahui bahwa pada aspek kualitas materi memperoleh skor sebesar $97.82 \%$ dengan kategori baik, aspek kesesuaian bahasa memperoleh skor 100\% dengan kategori baik, aspek penyajian mendapatkan skor sebesar 98.34\% dengan kategori baik, aspek kemudahan penggunaan media mendapatkan skor $94.20 \%$ dengan kategori baik dan aspek manfaat mendapatkan skor 99,66\% dengan kategori baik. Secara keseluruhan 
pengujian kualitas media memperoleh skor dengan persentase yang tinggi di atas 90\%. Dengan demikian, keduanya berpredikat layak digunakan.

Ditinjau dari aspek kualitas materi dalam media insektarium dan herbariumdapat disajikan dalam Tabel 4.dan Tabel 5. Aspek ini mengkaji sesuai tidaknya materi ajar tuntutan kurikulum 2013 dengan materi yang ada di dalam media pembelajaran.

Tabel 4. Hasil Analisis Kesesuaian Materi dalam Media dengan MateriTuntutan Kompetensi Dasar 3.8

\begin{tabular}{|c|c|c|c|}
\hline $\begin{array}{l}\text { Penjabaran } \\
\text { No. dari KD } 3.8\end{array}$ & $\begin{array}{l}\text { Materi Ajar } \\
\text { Tuntutan } \\
\text { Kurikulum } \\
2013\end{array}$ & $\begin{array}{c}\text { Materi yang } \\
\text { Disajikan di Media } \\
\text { insektarium }\end{array}$ & Keterangan \\
\hline \multirow{2}{*}{$\begin{array}{l}\text { Prinsip } \\
\text { klasifikasi } \\
\text { untuk } \\
\text { menggolo } \\
\text { ngkan } \\
\text { hewan ke } \\
\text { dalam } \\
\text { filum }\end{array}$} & $\begin{array}{l}\text { Ciri-ciri } \\
\text { umum } \\
\text { Animalia. }\end{array}$ & $\begin{array}{l}\text { Tersedia dengan } \\
\text { penjelasan tentang } \\
\text { ciri umum } \\
\text { invertebrata }\end{array}$ & Terpenuhi \\
\hline & $\begin{array}{l}\text { Ciri dan } \\
\text { klasifikasi } \\
\text { hewan } \\
\text { Invertebrata } \\
\text { dan } \\
\text { vertebrata }\end{array}$ & $\begin{array}{l}\text { Mengelompokkan } \\
\text { insekta sebagai } \\
\text { anggota dari filum } \\
\text { arthropoda }\end{array}$ & $\begin{array}{l}\text { Terpenuhi dari } \\
\text { segi ciri } \\
\text { invertebrata, } \\
\text { belum terpenuhi } \\
\text { bagian } \\
\text { vertebrata }\end{array}$ \\
\hline $\begin{array}{l}\text { Pengamat } \\
\text { an } \\
\text { anatomi } \\
\text { dan } \\
\text { morfologi } \\
\text { hewan }\end{array}$ & $\begin{array}{l}\text { Ciri anatomi } \\
\text { dan } \\
\text { morfologi } \\
\text { invertebrate } \\
\text { dan } \\
\text { vertebrata }\end{array}$ & $\begin{array}{l}\text { Tersedia awetan } \\
\text { insekta yang } \\
\text { dikelompokkan } \\
\text { ke dalam ordo } \\
\text { insekta }\end{array}$ & $\begin{array}{l}\text { Terpenuhi dari } \\
\text { segi morfologi } \\
\text { hewan } \\
\text { invertebrata. } \\
\text { Belum terpenuhi } \\
\text { dari segi } \\
\text { anatomi } \\
\text { invertebrata }\end{array}$ \\
\hline $\begin{array}{l}\text { Peranan } \\
\text { hewan } \\
\text { dalam } \\
\text { kehidupan }\end{array}$ & $\begin{array}{l}\text { Peranan } \\
\text { hewan } \\
\text { Invertebrata } \\
\text { dan } \\
\text { Vertebrata } \\
\text { dalam } \\
\text { kehidupan }\end{array}$ & $\begin{array}{l}\text { Tersedia melalui } \\
\text { penjelasan tentang } \\
\text { tujuan proses } \\
\text { pengawetan } \\
\text { serangga dan } \\
\text { tingkah laku dari } \\
\text { hewan }\end{array}$ & $\begin{array}{l}\text { Terpenuhi dari } \\
\text { peranan } \\
\text { invertebrata, } \\
\text { tetapi belum } \\
\text { terpenuhi dari } \\
\text { peranan hewan } \\
\text { vertebrata }\end{array}$ \\
\hline
\end{tabular}

Tabel 5. Hasil Analisis Kesesuaian Materi dalam Media dengan MateriTuntutan Kompetensi Dasar 3.3

\begin{tabular}{|c|c|c|c|c|}
\hline No. & $\begin{array}{c}\text { Penjabaran } \\
\text { dari KD } 3.3\end{array}$ & $\begin{array}{c}\text { Materi Ajar } \\
\text { Tuntutan } \\
\text { Kurikulum 2013 }\end{array}$ & $\begin{array}{c}\text { Materi yang } \\
\text { disajikan di media } \\
\text { insektarium } \\
\end{array}$ & Keterangan \\
\hline I. & $\begin{array}{l}\text { Prosedur } \\
\text { pengklasifik } \\
\text { asian } \\
\text { makhluk } \\
\text { hidup dan } \\
\text { benda- } \\
\text { benda tak } \\
\text { hidup }\end{array}$ & $\begin{array}{l}\text { Prosedur } \\
\text { pengklasifikasian } \\
\text { makhluk hidup } \\
\text { dan benda mati }\end{array}$ & $\begin{array}{l}\text { Tersedia dengan } \\
\text { penjelasan tentang } \\
\text { prosedur } \\
\text { pengklasifikasian } \\
\text { tumbuhan paku }\end{array}$ & $\begin{array}{l}\text { Terpenuhi untuk } \\
\text { tumbuhan paku } \\
\text { saja, belum } \\
\text { terpenuhi untuk } \\
\text { tumbuhan jenis } \\
\text { lain, hewan, dan } \\
\text { benda tak hidup }\end{array}$ \\
\hline 2. & Kerja ilmiah & $\begin{array}{l}\text { Menggunakan } \\
\text { prosedur ilmiah }\end{array}$ & $\begin{array}{l}\text { Tersedia dengan } \\
\text { penggunaan } \\
\text { prosedur ilmiah }\end{array}$ & Terpenuhi \\
\hline \multirow[t]{2}{*}{3.} & \multirow[t]{2}{*}{$\begin{array}{l}\text { Mengklasifi } \\
\text { kasikan } \\
\text { makhluk } \\
\text { hidup dan } \\
\text { benda tak } \\
\text { hidup } \\
\text { berdasarkan } \\
\text { ciri yang } \\
\text { diamati }\end{array}$} & $\begin{array}{l}\text { Klasifikasi } \\
\text { makhluk hidup } \\
\text { termasuk hewan } \\
\text { dan tumbuhan } \\
\text { berdasarkan ciri- } \\
\text { ciri yang diamati }\end{array}$ & $\begin{array}{l}\text { Pengklasifikasian } \\
\text { tumbuhan paku } \\
\text { berdasarkan ciri } \\
\text { morfologinya }\end{array}$ & $\begin{array}{l}\text { Terpenuhi } \\
\text { pengklasifikasian } \\
\text { tumbuhan paku, } \\
\text { tetapi belum } \\
\text { terpenuhi } \\
\text { pengklasifikasian } \\
\text { tumbuhan jenis } \\
\text { lain dan hewan }\end{array}$ \\
\hline & & $\begin{array}{l}\text { Klasifikasi benda } \\
\text { tak hidup }\end{array}$ & - & Belum terpenuhi \\
\hline
\end{tabular}


Kemampuan daya ingat terhadap pengetahuan yang telah diperoleh tersebut sekitar 20\% dari apa yang didengar dan sekitar 50\% dari apa yang dilihat. Dengan demikian peranan penglihatan lebih dominan dalam menentukan kemampuan kognitif seseorang. Oleh sebab itu, penggunaan media yang lebih banyak menggunakan penglihatan dari pada pendengaran akan menunjang pencapaian tujuan pembelajaran (Arrijani, 2005: I40).

Ditinjau dari segi penyajian, media insektarium dan herbarium didesain sedemikian rupa sehingga menarik siswa.Media tersebut berupa specimen asli dari alam yang sengaja dibuat untuk menunjang pembelajaran di kelas tanpa harus berkunjung ke tempat asal tanaman atau hewan tersebut diperoleh. Sesuai pendapat Sobirin et all., (Afifah dkk, 20I4), gambar padamedia pembelajaran dapat membawa siswa ke tempat media tersebut berasal tanpa harus berkunjung kesana. Foto bertujuan untuk memberikan gambaran habitat asli tumbuhan dan serangga sehingga siswa dapat mengkaitkan awetan dengan kondisi di lingkungannya.

Ditinjau dari segi kemudahan dalam penggunaan, media pembelajaran harus mudah digunakan, mudah dibawa, serta tidak berbahaya.Hal ini sesuai pernyataan Ibrahim (Afifah dkk, 20I4), bahwa media pembelajaran harus memiliki kriteria mudah dibawa, mudah dipindahkan dan tidak berbahaya bagi siswa.

Sebetulnya tidak hanya kemudahan dalam penggunaan, dari segi kemudahan dalam pengumpulan bahan, biaya, waktu, maupun teknik pembuatan juga tetap harus dipertimbangkan. Dalam pengumpulan bahan insektarium, misalnya diperlukan waktu yang tidak sedikit, mulai dari penangkapan serangga yang membutuhkan kecermatan dan kesabaran, teknik menangkap dan membiusnya supaya tetap mempertahankan bentuk serangga asli, dan juga proses pembuatannya. Semua itu tetap diperhatikan dan dipertimbangkan sebelumnya.

Demikian halnya juga dalam pembuatan media herbarium, membutuhkan waktu yang cukup lama terutama dalam hal proses pengeringan specimen. Selain itu, tidak semua jenis tumbuhan pula mudah untuk diawetkan, bisa jadi berjamur atau busuk. Di samping itu, besarnya biaya pembuatan media juga penting untuk dipertimbangkan.

Media insektarium dan herbarium tidak membutuhkan ketrampilan khusus untuk mengoperasionalkan. Cukup dengan mengamati secara morfologis tumbuhan maupun hewan yang diawetkan. Selain itu penggunannya tidak terpacu pada waktu, karena media tersebut cukup praktis, bisa dibawa kemana-mana, dan dapat digunakan secara kondisional. Hanya saja dari segi pembuatan mungkin seorang guru harus memiliki ketrampilan yang cukup supaya media yang dibuat juga berkualitas.

Ditinjau dari segi manfaat, adapun manfaat dari media Insectarium dan Herbarium menurut para ahli adalah sebagai berikut. Menurut Muhadi (Sari, 2010: III), manfaat dari insektarium yaitu dapat digunakanuntuk menyampaikan atau menjelaskan suatu materi ajar, dapat digunakan dalam kegiatan evaluasi, minat belajar siswa dapat dirangsang, ide, dan konsep dapat dihadirkan dengan jelas. Media Insektarium dapat membantu siswa dalam mempelajari morfologi serangga secara langsung dengan objek yang disajikan dalam media. Sedangkan menurut Asyhar (2012), media sederhana berupa objek specimen memiliki kelebihankelebihan, antaranya memberikan pengalaman secara langsung, penyajianya yang secara konkrit dan menghindari verbalisme, dapat menunjukan objek secraa jelas serta dapat dibawa langsung ke kelas.

Menurut Munadi (2013: III), bahwa objek nyata/benda asli mempunyai kegunaan yang unik sebagai media pembelajaran, contohnya yaitu specimen yang kadang-kadang tidak dimodifikasi atau dimodifikasi. Karena dapat menyampaikan atau menjelaskan materi ajar. Bentuk yang unmodief mudah didapatakan di lingkungan. Meskipun demikian, media asli dari alam dapat menjembatani perbedaan situasi dalam pembelajaran. Hal ini sesuai pendapat Riandi (2010), bahwa media herbarium yang digunakan bertujuan agar dapat digunakan sebagai alat bantu pembelajaran dengan menampilkan obyek yang sebenarnya atau disebut media asli. Media asli sering disebut sebagai real karena media tersebut merupakan obyek nyata (real). Menampilkan obyek nyata di dalam kelas dapat memberikan pengalaman langsung kepada para siswa saat pemebalajaran. Media asli tidaklah sukar untuk mendapatkannya, di sekitar sekolah atau lingkungan tempat tinggal siswa banyak sekali objek yang dapat digunakan sebagai media pembelajaran biologi. Namun demikian penggunaan media asli dapat menjembatani perbedaan situasi pembelajaran dikelas dengan situasi kehidupan nyata.

\section{Simpulan}

Berdasarkan hasil analisis kualitas media pembelajaran Insektarium dan Herbarium tersebut dapat disimpulkan disimpulkan bahwa media Insectarium dan Herbarium memiliki kualitas yang baik dan berpredikat layak digunakan untuk menunjang pembelajaran.

\section{Daftar Pustaka}

Afifah, N., Sudarmin, dan Titi Widianti. 20I4. Efektivitas Penggunaan Herbarium dan Insektarium Pada Tema Klasifikasi Makhluk Hidup Sebagai Suplemen Media Pembelajaran IPA Terpadu Kelas VII MTs. Unnes Sciences Education Journal. 3(2): Semarang.

Anggraeni, Nofita. Pengembangan Herbarium Sebagai Media Pembelajaran Biologi Pada Materi Tumbuhan Paku (Pteridophyta) Siswa Kelas VII SMP. Skripsi. Yogyakarta: UAD.

Arrijani. 2005. Penggunaan Media Herbarium, Kartu Botani dan Ilustrasi Tumbuhan dalam Penguasaan Materi Perkuliahan. Tondano: FMIPA UNIMA. 
Arsyad, Azhar.2006. Media Pembelajran. Jakarta : PT. Raja Grafindo Persada.

Asyhar, Rayandra. 20I2. Kreatif Mengembangkan Media Pembelajaran.Jakarta : Referensi Jakarta.

Ilham Majid dan Sunarti Mulaicin. 2013. Pengembangan Media Pembelajaran Herbarium Pada Siswa Madrasah Aliyah Kota Ternate. Jurnal Bioedukasi. Vol 2, No I.

Mukaromah, Fathul. 20II. Seni Insektarium Pada Serangga Bersayap. Jurnal POPT Pertama. Surabaya: BPP2TP Surabaya.

Munadi, Yudhi. 20I3. Media Pembelajaran. Jakarta: GP Press Group.

Purwanti. 2012. "Herbarium". http://staff.uny.ac.id/sites/default/files/pendidika n/Purwanti\%20Widhy\%20Hastuti,\%20S.Pd.,\%20 M.Pd./I2th\%20herbarium.pdf. Diakses Tanggal I5 April 2014.

Riandi.20I0.”Media Pembelajaran Biologi”.http:// file.upi.edu/Direktori/FMIPA/JU R._PEND._BIOLOGI/I963050I I98803IRIAN DI/Bahan_Kuliah/MediaPembelajaranBiologi.pdf. Diakses tanggal 20 Januari 2014

Rizkyana, Aulia. Pengembangan Insektarium sebagai Media Pembelajaran Biologi Pada Materi Insekta untuk Siswa Kelas X SMA/MA. Yogyakarta: UAD.

Sari, S.M. 2013."Pengembangan Insektarium Ordo Coleoptera Sebagai Media Praktikum Biologi di SMA Negeri IO Jambi”. Skripsi. Jambi: Universitas Jambi. 